\title{
Authenticity in Holocaust literature for children
}

\author{
M.P. Machet \\ Department of Information Science, University of South Africa, P.O. Box 392, Pretoria, 0003 Republic of South Africa
}

machemp@alpha.unisa.ac.za

\begin{abstract}
Many children's novels have been written about the Holocaust to try and make this period accessible and meaningful to children. Novels can help children become aware of the Holocaust by conveying some of the complexity of the historical situation and also by personifying the events through fictional characters with whom children can identify. However, if one wishes to achieve these aims then it is important to choose books that are authentic. In this article some criteria for authenticity of the representation of the Holocaust and Jewish characters will be advanced and considered in conjunction with the reasons for making books on this topic available for children. Certain books will then be evaluated according to these criteria.
\end{abstract}

Die Holocaust as tema word deur heelparty kinderboeke gebruik om hierdie periode meer toeganklik en betekenisvol vir kinders te maak. Boeke kan help om kinders bewus te mak van die Holocaust deur die kompleksiteit van die historiese gebeurtenis oor te dra en om gebeure deur middel van fiktiewe karakters te verpersoonlik sodat kinders daarmee kan identifiseer. Indien hierdie doelwitte bereik wil word, is die seleksie van geloofwaardige boeke belangrik. Hierdie artikel poog om kriteria vir die geloofwaardige uitbeelding van die Holocaust en Joodse karakters daar te stel en te verduidelik waarom hierdie tema aan kinders bekendgestel moet word. 'n Aantal boeke word aan die hand van die gestelde kriteria geëvalueer.

The Holocaust was a watershed event in the history of humanity and many children's novels have been written to try and make this horrific period accessible and meaningful to children. Parsons and Totten (1997) state that fictional books are an important means of helping children become aware of the Holocaust. They can convey some of the complexity of the situation and help translate statistics into people with whom children can identify. A good book will also avoid oversimplification of a complex historical event and help children better understand the many factors that ultimately led to the Holocaust. Books help to give children insight into the feelings of people at that time. They can help children develop a deeper respect for human decency by providing credible models of heroism and dignity who transcended the evil of the Nazis. Children also will be able to examine the moral choices that were open to people: victim, oppressor, bystander or rescuer. They can analyse the corruption of language used by the Nazis to disguise their evil intent, for example, emigration for expulsion, final solution for the planned annihilation of every Jew in Europe.

If one wishes to achieve these aims then it is important to choose books that are authentic because books, novels and television are the primary means through which most children will gain their knowledge of the Holocaust (Wood 1992:358). In this article some criteria for authenticity of the representation of the Holocaust and Jewish characters will be put forward and considered in conjunction with the reasons for making books on this topic available for children. Certain books will then be evaluated according to these criteria.

\section{Authenticity}

The Concise Oxford dictionary (1981:58) defines authentic as 'reliable trustworthy; of undisputed origin, genuine'. Authenticity can thus be assumed to include genuine portrayals of cultures and avoidance of stereotyped characters. It is particularly important that stereotypes be avoided in Holocaust children's literature because stereotypes were one of the means used by Nazis to create anti-Semiticism and to alienate Jews. A stereotype is defined by Leveson (1996:1) as

'a generalised and often exaggerated image of a group of people, constructed from scanty and insufficient evidence, and commonly accompanied by prejudice, either negative or positive'.

Shain states (1994:5) that a stereotype is a complex mental construct (or set of images) which is automatically associated with a word and is seen as factual rather than belief because of consensual validation. Stereotypes of Jews have remained relatively consistent through a long period of time.

The origin of Western anti-Semiticism is the religious stigma based on the crucifixion myth, where the Jews are seen as the murderers of Jesus. The religious stigma was reinforced by an equally powerful economic stigma whereby Jews are seen as the incarnation of monetary values. Both stereotypes have persisted to the present day (Leveson 1996:35) and are still found in children's books such as In die hemel eet ' $n$ mens mieliepap by Maretha Maartens (1991). The racial or eugenic form of antiSemiticism emerged at the beginning of the 20th century. Jews were believed to be intellectually and biologically 
different and inferior to the Aryan or Nordic nations and unable to be assimilated. This form of racism reached its peak in Nazi Germany and became the motivating rationale behind the eliminationist anti-Semiticism whereby the only way to preserve the Aryan races from contamination was to eliminate the Jewish race entirely in the Final Solution in the Holocaust (Leveson 1996:35). Tötemeyer (1984:8) contends that racists attribute cultural differences to biological factors, in that forms of behaviour, habits and customs are considered to be inborn rather than learned.

The way characters are presented are of particular importance in children's books because research indicates that children's racial attitudes are formed by contact with the prevailing attitude of their communities about those races, rather than by contact with people of other races (World Council of Churches 1979:11). Frequently the only contact a child may have with another race is through the pages of a book. The way the group is portrayed in the book can therefore be very influential in forming the child's perceptions and attitudes towards the race.

Mo and Shen (1997:86) identify accurate historical information and cultural details as important aspects of authenticity. Although historical accuracy in terms of the Holocaust can be a difficult issue as so much of the history is too horrific to portray accurately in books intended for children, if the Holocaust is not to be trivialised it is essential that the facts are presented as accurately as possible within these constraints. It must also be taken into account that children have limited knowledge and experience of an event like the Holocaust. They cannot compare representations with other representations they have encountered or recognise fine shades of meaning, nuances or moral gradations.

A form of historical inaccuracy, which can even be regarded as historical revisionism, is to present the Holocaust as simply a consequence of the war. The suffering of the Jews is then presented as similar to suffering of others in the war. Wood (1992:360) quotes Friedlander who calls this the 'symmetric version of the past' wherein the crimes of the Nazis are matched with the destruction wrought by the Allied forces. While Nazi crimes are not denied in these symmetric narratives, Allies join the Nazis in the category of potential 'perpetrators'.

Hearne (1993:34) further suggests that there should also be cultural authority. This means that an author distinguishes the values, facts and attitudes that members of the culture as a whole would consider 'worthy of acceptance and belief'. This implies that some cultural values, attitudes or beliefs may be realistically reflected in a story but may not be authentic because members of a culture do not always agree with each other on those values. Cultural values are constantly changing and adapting, they are not static. When the version of culture can be accommodated inside the range of values acceptable within the social group, then the author has achieved a measure of authenticity. When a book is written about one culture but intended for another culture, the author may have to make adaptations so that the book will be acceptable to the other culture. Mo and Shen (1997:90) suggest that adaptation is a process of cultural filtering to make the book accessible to the anticipated audience. However, this filtering is unacceptable if it means the book no longer reflects or has perverted the cultural values of the original culture.

\section{Authenticity and stereotyping}

As stated above, in order to be authentic, books need to avoid stereotyping. Cheyette (1993:268) emphasises that the stereotypical Jew in literature is anything but simple. Writers do not simply draw on a mythic representation but actively construct an image in relation to their own political and literary concerns. Shain (1995:78) states that there are many common stereotypes of Jews used in literature which consist of a racist component as well as a moral component. Physical indications of race are the large nose, darker skin tone and thick lips. There is also a moral component to the stereotype - Jews are depicted as dishonest, money-grubbing, conniving and likely to cheat and deceive honest, trusting Christians. Allport (1979) in a study of prejudice found that the Jew in the Holocaust suffered a particular type of stereotyping namely the scapegoat. They were held to be accountable for the loss of the First World War and to be conniving with the Russians to take over the world. The contradictory images of the Jew as a Bolshevik as well as controlling the capital of the world indicates the illogicality of the stereotype.

The Afrikaans book, In die hemel eet 'n mens mieliepap by Maretha Maartens (1991), uses racially based stereotypes and reinforces racist perceptions. An Afrikaans girl comments on Daniel's nose 'It is so hooked, just like a lucerne sickle'. Daniel replies, 'We Jews have such noses. It is our ... trade mark' (p. 6). She also comments on his swarthy skin colour (p.7). While standing in a queue for bread in Munich he sees some concentration camp inmates dragging a wagon. He asks a woman standing in the queue who they are. She replies, 'But you are also Jewish ... How can you venture out on the streets?' (p. 41). Daniel thinks about her comment and realises 'The boys that pulled the wagon, all had the Jewish nose' (p. 42). This implies that every Jew has a particular nose that makes them instantly recognisable almost like the mark of Cain. When he is arrested and on the transport to Dachau, he talks to another boy who says to him,

'You were born with the wrong nose and the wrong skin and the wrong colour hair and the wrong forefathers. Hitler thinks we are all busy impoverishing the Germans and who knows what else. You are the Jewish Problem and the Germans do not care a rap if you live or if you die' (p.50).

This book set out to present a sympathetic image of the Jewish protagonist but the author's use of stereotypes defeats this objective. 
The underlying symbolism also reflects the basic ethnocentrism of the author. Daniel who is only half-Jewish is given the option which religion he will choose to follow Judaism (like his father) or Protestantism (like his mother). He has chosen to be a Protestant and his mother feels this will give him the courage to survive in Germany. She tells him that Jesus was victorious and 'He will make those that choose Him, also victorious' (p. 14). The constant underlying message in the book is that this will save him ultimately from the Nazis. While in the camp he also prays to Jesus, King of the Jews. When Daniel is rescued by his uncle there is a strong implication that it is as a result of his acceptance of Jesus whilst the Jews (who do not accept Christ as their saviour) are left to die with no hope of rescue.

Another South African novel, although not racist, also contains anti-Semitic stereotypes. 'n Roofvoël uit die Ooste by Rona Rupert (1995) is the story of Emma, a young Afrikaans girl who becomes friends with Szymon, a Jewish boy who has fled from Lithuania. Emma's mother falls pregnant and her parents come to town to see a doctor. Emma asks why they did not call Dr Pintusewitz to see her mother. The father replies 'He's a Jew ... Your mother would not have liked it'. Emma asks 'What is wrong with Jews then?' Her father replies

'They are not our sort of people ... They are people that live according to their own law. They do not eat our food and they will not sit next to us at table. They do not go to our church and they do not want their daughters to marry our sons ... They want to be a separate people. They believe they are chosen above other people'.

Emma replies that it is what Afrikaners do as well in respect of the English and asks what is the difference. Her father replies: 'It is the Jews that took Christ prisoner' (p. 378). Although Emma does not accept these views, the statement about Jews being Christ killers is not questioned or refuted in the book. Young children would be left with this undisputed statement.

Rona Rupert subverts the standard stereotype of Jews having long noses in this book. Emma thinks of noses. Her father has a long nose, so does Szymon, and Szymon's uncle. She decides that she likes long noses. By grouping her father with Szymon she emphasizes that it is not only Jews who have long noses and she turns it into a positive characteristic.

The novel The final journey by Gudrun Pausewang (1996) is generally excellent. It deals with Alice's final journey to Auschwitz. However, at one point Alice, who has been kept ignorant of the terrible events in Germany by her grandparents, asks Rebekka why others do not want the Jews.

'We are too clever for them', said Rebekka. 'It makes them envious'.
'We have learned a lot', added Aaron, 'because we have always been persecuted and had to fight for our lives ...'

'... We are simply different', said Rebekka. 'That's why we are always the scapegoats' (p. 110).

This statement reflects the standard stereotype of the clever Jew. Although this image is rationalised by saying Jews are clever because they have been persecuted, it still reflects the view that Jews are somehow different which is also one of the reasons for their persecution.

\section{Cultural authenticity}

Cultural authenticity should include accurate cultural details and reflect values and attitudes generally accepted by the culture. A book needs to have culturally authentic and credible Jewish characters if it is to give children real insight into this era and not distort the issues. In the novel Reunion by Fred Uhlman (1994) the Jewish characters do not have any of the traditional cultural values associated with Jews and there is little to distinguish them from the German characters. For example, the characteristic warmth normally found in Jewish homes, particularly between a mother and only son, is missing in this novel (McClelland 1961:364). Hans, the Jewish protagonist, describes his encounters with his mother as follows:

'Occasionally, with a nervous movement, she put a hand tentatively on my shoulder, but she did this more and more rarely, sensing my resistance to even such mild demonstrativeness. Only when I was ill did I find her company acceptable and surrendered gratefully to her repressed tenderness' (p. 52).

The family does not follow the Jewish religion, live a traditional Jewish life or identify with Zionism. The only religious faith which Hans has is the belief in a benevolent God. He has been brought up with little Jewish education or knowledge of the religion. His father is an agnostic and his mother, although she attends synagogue on Day of Atonement (the most religious day in the Jewish calender), sings carols on Christmas Day. She donates money for Jewish children but also gives money for the conversion of Jewish children to Christianity in Poland. Although the family does not deny they are Jewish this means

'little more than that once a year, on the Day of Atonement, my mother would go to a synagogue and my father would neither smoke nor travel, not because he believed in Judaism but because he didn't want to hurt people's feelings' (p. 48).

This depiction of Jewish characters may be historically correct as there were many German-Jews who were assimilated. However in a Holocaust novel, specifically focussing on the suffering that was inflicted on GermanJews, it is inappropriate to emphasise the family's lack of faith and commitment to Judaism, especially as this contributes little to the story. 
The family is fully committed to Germany and sees themselves as German not Jewish. The extent of this commitment is illustrated by an incident when someone collecting for the Zionists in Israel comes to Hans' father. The father is furious and refuses to donate any money. He feels Jews claiming Israel made no more sense than the Italians claiming Germany because it was once occupied by the Romans. The Zionist accuses the father of being an assimilant. The father replies proudly that he is indeed an assimilant.

'I want to be identified totally with Germany. I should certainly favour the complete absorption of the Jews if I could be convinced it would be of lasting profit to Germany ..' (p. 49).

This statement about the absorption of Jews in Germany parallels Hitler's plan of eliminating all Jews from Germany. If a Jew is able to make a statement like this then the implication is how can the reader blame Germans for agreeing.

One of the aspects of cultural authenticity is that in some of the Holocaust books published in Germany the Nazis and Jews are both represented as being outside mainstream German life. Germans are presented as the good people with whom the children can identify whilst Jews and Nazis are presented as the 'other'.

The Germans are shown as helpless against the brutal force of the Nazis who are somehow not German. For example, in Reunion by Uhlman (1994) the character Konstantin, the ultimate aristocratic German, is not antiSemitic, he is even prepared to make a Jew his best friend. However, his mother is virulently anti-Semitic - but she is a Pole. Hans confronts Konstantin and asks him why he would not introduce him to his parents - was he ashamed of him. Konstantin replies:

'I didn't dare to introduce you. The reason, I swear by all the gods, has nothing to do with being ashamed - there you're wrong - it is far simpler and more unpleasant. My mother comes from a distinguished - once royal - Polish family, and she hates Jews. For hundreds of years Jews didn't exist for her people, they were lower than the serfs, the scum of the earth, untouchables. She detests Jews. ... She believes you are in the service of world Jewry, which is only another word for Bolshevism' (p. 72).

The father who belongs to the German nobility is different. Konstantin states:

'My father hardly cares whom I meet. For him, a Hohenfels will always be a Hohenfels wherever he is and whomever he meets. Perhaps if you were a Jewess it might be different. He'd suspect you of wanting to hook me. And he wouldn't like that at all. Of course if you were immensely rich he might, he just might consider a marriage possible' (p. 72).

The vulgarity of this statement as well as the arrogance of believing that their nobility is inherent and cannot be soiled or demeaned by association with a Jew is accepted by Hans without question. Hans' perception of their inherent nobility appears to be similar to their own opinion.

Naziism is introduced into the school by outside forces. There is no Nazi influence in the school until a new teacher who comes from Prussia joins the school. 'Until then ... the school had been a temple of humanities into which the Philistines had never managed to introduce their technology and their politics'. The reference to technology is interesting as it is of course the use of technology which enabled the Nazis to practice mass murder. The author continues, 'To die for one's country had been to follow their time-honoured example ... But to take part in political strife, this was another story' (pp. 75-76). The boys are above the political activities going on elsewhere in Germany until their new history teacher arrives. He speaks with a different accent and talks to them about the 'dark powers' at work everywhere, America, Germany and especially Russia. This dark power is determined to destroy the 'gift' that the Aryans have inherited. They are a superior race being destroyed by barbarians. These precepts are accepted by the 'duller boys' but not by the more intelligent boys. However, this is the beginning of anti-Semiticism in the school.

Hans' father decides that Hans should leave Germany and go to an uncle in America. Hans receives a letter from Konstantin (who has dropped his friendship with Hans) in which Konstantin states that he thinks Hans has made the correct decision. After much thought Konstantin has decided to join the Nazi party. He states that his reason is that he 'can't see any other hope for Germany. Our choice is between Stalin and Hitler and I prefer Hitler' (p.85). He is sorry that Hans will have to leave Germany for a time but he is sure that he will be able to return in a few years. 'I am convinced that the Führer is perfectly able and willing to choose between the good and undesirable Jewish elements' (p. 85). The reader is shown that even this boy, the epitome of the 'good' German, the perfect Aryan nobleman, is taken in by Hitler.

Years later Hans receives a request from his old school for a contribution to help rebuild it as it was destroyed during the war. Included with the request is a list of all the boys who died in the war. Hans forces himself to look up Konstantin's name and finds that he was executed because he was involved in the plot to assassinate Hitler. Thus at the end Konstantin redeems himself with a heroic action. The reader is left to draw the conclusion that this embodiment of the 'good' German realised the error of his ways, tried to make compensation and paid with his life. In the book Reunion it is Konstantin who is the hero and the embodiment of the German ideal - noble, good-looking, brave, intelligent and committed to the good of Germany.

The novel Friedrich by Richter (1987a) was written originally in German and deals with the Holocaust from the German perspective. It is the story of two young boys who become friends, a Jewish boy, Friedrich and the German 
boy who lives in the apartment below who is the narrator of the story. The book is similar in many respects to the novel by Uhlman. It too shows the good German being deceived and taken in by the Nazis who are often presented as outsiders. Friedrich's father is comfortably off whereas the narrator's father is unemployed and subsidised by the grandfather. This reflects to some extent the stereotype of the rich Jew and the poor but deserving German who, in spite of his best efforts, cannot find work.

Friedrich is anxious to participate in the everyday activities of boys his age and goes with the narrator to a meeting of the Jungvolk, a Nazi youth movement. That evening there is a special visitor to the group - a hunchback man who has come to warn them of the danger of the Jews. It is interesting that the man is a hunchback as stereotypical pictures of Jews used for propaganda often depicted the Jew as a hunchback. At the end of his speech he makes the boys repeat: 'The Jews are our affliction'. He picks Friedrich out of the boys to say it on his own. A distraught Friedrich says it but runs from the room directly afterwards (pp. 35-38). Although the narrator is best friends with Friedrich he does not offer help to Friedrich or leave with him. He is helpless in the face of pressure and in the threatening environment that pervaded Germany at this period.

The Nazi Party is presented as offering so many benefits for Germans that even the Jewish family can sympathise with the German's wish to join the party. Friedrich's father, when he is told by his neighbour that he has joined the Nazi Party states: 'I understand you very, very well. Perhaps - if I weren't a Jew - perhaps I would have acted just like you. But I am a Jew' (p. 70).

Friedrich goes with the narrator to a Jungvolk meeting and tries to go see the film Jud Süss, an anti-Semitic movie. The Jewish protagonist identifies with Germany to the extent that he is prepared to participate in groups that are determined to eliminate the Jews. If the Jews wanted to be part of Nazi Germany, how can the reader blame the German protagonists for joining the Nazi Party and participating in their activities.

The German family participates in anti-Semitic acts in spite of their friendship with the Jewish family and a professed reluctance. On Kristallnacht, the narrator is drawn in and participates in the destruction of Jewish property. The implication is that it was easy for ordinary 'good' German people to be drawn into the anti-Semitic furore.

The book ends with Friedrich's death. His mother died after Kristallnacht and his father has been taken off to a concentration camp. During a bombing raid Friedrich begs to be allowed to enter the bomb shelter. He is evicted even though they can hear heavy bombing outside. A sergeant tries to intervene saying that one would not even put a dog out into that, but he is helpless in face of the Nazis who tell him that Friedrich is a Jew. The sergeant tells the boy to go quietly 'otherwise there will be nothing but annoyance' (p. 136). After the air raid they find Friedrich apparently sitting on the stoop. Resch, the caretaker of the building, kicks him and he falls over. They realise he is dead. Resch says, 'His luck that he died this way' (p. 138).

Friedrich is shown as not even deserving the same consideration that a dog would be shown. The irony is that Resch's comment is true: Friedrich is fortunate to have died that way rather than in a concentration camp.

The book presents the Jewish family sympathetically and tries to show the pressures that ordinary Germans were put under to conform to anti-Semiticism. However, there is no attempt by any ordinary German to defend the Jews although many seem sympathetic to them. For example, the Teacher Neudorf tells the story of the persecution of the Jews when Friedrich is forced to leave the German school and attend a Jewish school in 1934 (pp. 60-64). Although both books are written as sympathetic portrayals of Jews and are critical of the Nazi system the subtext gives the reader a different message. The 'good' Germans are the ones that evoke sympathy because the Jewish characters lack cultural validity. They have no identification with Jews or Judaism. They strongly identify with Germany and see themselves as completely German. In Friedrich the Jewish protagonist attempts to join the Jungvolk and in Reunion the father would recommend Jews assimilating if this was to the benefit of Germany. The Jewish characters almost comply in their ultimate fate. Although the Germans did not resist the Nazis, neither did the Jews.

\section{Historical accuracy}

Historical accuracy in terms of Holocaust literature for children is a difficult concept. The real horrors of the Holocaust need to be softened or avoided to some extent as children should not be exposed to events such as medical experimentation carried out in Auschwitz. However, authors need to find ways of presenting the realities of the Holocaust as otherwise it becomes trivialised. An excellent example of a book that succeeds in doing this is The final journey by Pausewang (1994). She succeeds in presenting the realities of Alice's journey and final fate very subtly. Alice has been protected from knowledge of what was happening to Jews in Germany by her grandparents. During the journey, through conversation with other inmates of the cattle car combined with flashbacks, Alice comes to realise the truth of their situation as Jews. This is a clever technique used by the author as it not only heightens the tension in the story but is also a good way of introducing background information to a child who may not be familiar with some of the events of the Holocaust. In addition, by describing them in this way the events do not have the horror of immediacy. Alice's initial incredulity and reluctance to accept the unbelievable facts reflects what a young reader may feel at being confronted with the realities of the Holocaust. The reader is gradually drawn into the book and Alice's world.

The hardships of travelling in a cattle car with no water being provided, no toilet facilities, no space and worst of all no idea of the final destination is graphically described. 
The problems encountered, such as the lack of any toilet facilities, is highlighted as well as the valiant attempts of people to overcome these problems and still retain some dignity. The book does not try to soften the realities for the child reader.

The book ends with their arrival at Auschwitz. The truck slowly comes to a stop and the inmates start organising their luggage. Everyone is ordered out by men in striped clothing. Alice is reluctant to leave the body of her grandfather, who has died during the trip, and wants to know where he will be buried. The man lifting her out assures her that he will find her and tell her where the bodies are buried. She tells him her name is Alice Dubsky and he replies 'Alice in Wonderland ... That's easy to see'. The irony in calling her 'Alice in Wonderland' reflects on her previous life of ignorance as well as her present condition. The world created by the Nazis was fantastical, beyond the belief of any sane person. It also refers to a childhood that Alice (and many other children) should have had, but did not.

Old people and small children are loaded onto lorries and taken away. The others are lined up and marched towards the camp. A German man stands at the entrance and indicates whether people must go left or right. Alice asks where they are going and is told to the showers. She is relieved that she will once again be clean and get rid of all the muck from the journey. The book ends with Alice waiting for the shower to start.

'Alice tipped back her head. Soon, soon, water would pour down over her from the nozzle up there. The water of life. It would wash her clean of the dirt and horror of the journey, would make her as clean as she had been before. She raised her arms and opened out her hands' (p. 154).

The title of the book has prepared the reader for the shocking end. Alice may be unaware of what awaits her but the reader knows that this was Alice's 'final journey'.

Although the ending is without hope this powerful book contains a positive message to children in terms of the humanity shown by the passengers to each other. The characters are presented very realistically, there is bickering and arguments in the confined space but people try to help and support each other and do not become dehumanised in the most dehumanising of circumstances. Only the Germans are shown to be without any compassion towards their helpless prisoners. This book is not only historically accurate but has authenticity in terms of cultural validity and characterisation.

In contrast with this the Afrikaans book In die hemel eet ' $n$ mens mieliepap by Maretha Maartens has little historical accuracy. The novel tells the story of fifteen-year-old Daniel Rosendorf, a half-Jewish German boy. Daniel and his sick mother are visiting her family in Bloemfontein, a town in South Africa. Daniel's father writes and requests that Daniel return to Germany to help him with his younger sister who is handicapped. After due consideration Daniel's mother agrees to his return, although she will remain in South Africa because of her illness. This is most unlikely. On 15 September 1935 the Nuremberg laws were passed and one of these laws prohibited marriage between German citizens and Jews and gave Germans the opportunity to divorce a Jewish spouse. The laws also disenfranchised Jewish citizens. Daniel, with a Jewish father, would have been classified as half-Jewish. No Jewish father would have asked a child to return to Germany, nor is it likely that a mother would have allowed a child to return. In addition, the Jews in Bloemfontein by that time were fully aware of the precarious position of the Jews in Germany and other occupied countries. The author, although purporting to have written the book out of sympathy with the Jews after visiting Dachau, has not paid attention to historical detail that would have added to the book's crediblity. Daniel is finally rescued by his uncle, an extremely improbable situation. There is little discussion of how someone from South Africa, a country at war with Germany, would have been able to travel from South Africa during wartime, enter the country, find out where his nephew was incarcerated and persuade the Germans to release him.

Maretha Maartens also shows a lack of knowledge about Jewish law and tradition. Daniel says that his mother is Protestant and his father an orthodox Jew. The children were allowed to choose which religion they will follow ( $p$. 6). In orthodox Judaism a child is Jewish only if the mother is Jewish, otherwise the child must be converted. He also states that a letter from his father is written in Hebrew (p. 2 ). This is most unlikely as the language used would be Yiddish not Hebrew. Even this is unlikely as it would probably have been German since his mother is not Jewish. Although these are small details it shows a lack of respect towards her subject. If a writer wishes to write about a culture not her own, she should at very least ensure that details such as these are correct.

As discussed earlier another form of historical inaccuracy is to present the Holocaust as only one of the terrible events during the Second World War. The Jews are then presented as just one of the many groups who suffered during the war. Rona Rupert's (1995) book 'n Roofvoël uit die Ooste falls into this category.

Szymon is a Lithuanian Jew and has been forced to flee leaving his parents and siblings behind. He forms a friendship with an Afrikaans girl, Emma. Fat William, an antiSemitic child in the school, puts a cutting on Emma's desk about 30000 cats who have been killed in Paris for food. Fat William knows that this will upset Emma who is very fond of cats and has a pet cat of her own. Emma tells Szymon of this incident. Szymon tells her in return that his family have been taken to Treblinka and that there are no more Jews in Lithuania. Emma apologises for the pettiness of her complaints about Fat William in comparison to Szymon's problems. Szymon replies: 'It is the same thing' (p. 68). Although this can be interpreted that they are both forms of senseless cruelty and victimisation, it is a 
revisionist statement to compare a piece of cruel teasing about the death of cats with the planned elimination of Jews. Both may grow out of cruelty and disrespect for the beliefs of people, but the extremity of the Nazis actions should not be put in the same category as William's action.

The horror of the fate of the Jews in Europe is hinted at but never explicitly stated nor are the reasons for it discussed. It is shown against a backdrop of general suffering during the war including the drought in the Karoo. The implication is that it is part of the general suffering during the war and not something separate or unique.

A problematic book is Let the celebrations begin by Margaret Wild and Julie Vivas (1992). This is a picture book about a party for the children that took place after the liberation in Belsen Concentration Camp. The extract at the beginning of the book states that: 'A small collection of toys has been preserved which were made by Polish women in Belsen for the first children's party held after the liberation'.

This extract does not make it clear if these women were Jewish or not. However, in the book the names of the characters are all Jewish rather than Polish: Miriam, Sarah and David. The atmosphere in the book is almost lighthearted. People are aware that liberation should be soon. The book is brightly coloured although the colours of the clothes of people are very subdued. The people are depicted as ragged and thin and almost resemble rag dolls. However, there is no explanation of why the people are there or who they are. The book is aimed at children of three to six years old and the pictures of these rag doll people will be confusing. Children of this age are too young to be introduced to the concept of the Holocaust and the triumph of spirit will be lost on them if they cannot understand the circumstances of the camp. The camp is also almost cheerful. The children are shown playing a game. No German soldiers are shown, although it is probable that by this time most of the soldiers had fled.

The liberating soldiers' horror at what they find is conveyed by the following description:

'David peeps at the soldiers through his mamma's old black shawl, and the soldiers stare back at us, oh, so strangely, making soft noises in their throats.

They seem afraid to touch us - it's as if they think we might break' (p. 22).

However, the spell is soon broken and the soldiers laugh and play with the children. The fragility of most of the prisoners is not indicated. Children are unlikely to realise the depth of the soldiers' horror that the author tries to convey. This picture also does not tally with the horror of the reality. Belsen was the first camp liberated by the Allies. They found 10000 unburied dead and 28000 starving, sick and dying prisoners (Feig 1979:371).

This story would have been more appropriate for older children who can be introduced to some of the awful realities of the concentration camps. It is difficult to imagine what sort of understanding a young child would have of the circumstances and conditions portrayed in this book.

\section{Authenticity in Holocaust children's books}

The books discussed have all been written out of sympathy with the Jews and to show the evils of Naziism. However good intentions do not ensure authenticity. It is necessary to examine the subtext of books in order to establish the message being given to children. Although surface features of text may appear to satisfy the criteria listed at the beginning of this article for meaningful books for children, underlying attitudes and frameworks need to be carefully evaluated for authenticity. The use of stereotypes is unacceptable as this encourages racist categorisation of people. Further, it is important that if books include stereotypes that were current at the time that these stereotypical representations are queried. For example, in Rupert's book the traditional stereotype of Jews as Christ killers is not discussed. This type of stereotype should be shown to be one of the unacceptable tools used by the Nazis as part of their propaganda to mobilise anti-Semitic feelings in the general population.

To present Jews and Germans equally as victims of the Nazis cannot be regarded as authentic. This is not historically accurate. Nor is the presentation of Jewish characters finding the Nazi Party attractive historically accurate or credible. Many Jews were fully aware of the dangers of remaining in Germany. There were international conferences in Switzerland where these dangers were highlighted and discussed. The German Jews frequently had no option but to remain as no other country would take them. Also they were forced to sign over all their possessions and business interests to the German government before they could obtain permission to leave. To comply with the conditions they would often be left destitute and many were unable to face the prospect of life in a new country without any financial resources (Dawidowicz 1975:169-196; Friedman 1980:100-118; Richter 1987b:196).

It is recognised that German authors need to try and write about the national past in Germany in a way that will enable children to find acceptable national images of the Third Reich and come to terms with their guilt. However, these national images cannot be developed at the cost of perpetuating inaccurate images of Jewish characters.

Historical revisionism in the form of presenting the Holocaust as the result of war and part of the suffering inflicted on all people during the war trivialises the Holocaust and also makes it easier to excuse. If no-one was responsible then no-one has to feel guilt.

It can be concluded that if we wish children to attain a real understanding of the Holocaust and the events that led to it, books must be evaluated for authenticity. 


\section{Note}

All translations from the original Afrikaans were done by the author of the article.

\section{References}

Allport, G.W.1979. The nature of prejudice: 25 th anniversary edition. Reading, Mass.: Addison-Wesley Publishing.

Cheyette, B. 1993. Constructions of the Jew in English literature and society: racial representations, 1875-1945. Cambridge: Cambridge University Press.

Concise Oxford English dictionary of current English. 1982. 7th edition. Edited by J.B.Sykes. Oxford: Oxford University Press.

Dawidowicz, L. 1975. The war against the Jews 1933-1945. New York: Holt, Rinehart and Winston.

Feig, K.G. 1979. Hitler's death camps: the sanity of madness. New York: Holmes \& Meier.

Friedman, P. 1980. Roads to extinction: essays on the Holocaust. New York: Jewish Publication Society of America.

Hearne, B. 1993. Respect the source: reducing cultural chaos in picture books, part two. School library journal, 8:33-37.

Leveson, M. 1996. People of the book: images of the Jew in South African English fiction 1980-1992. Johannesburg: Witwatersrand University Press.

Maartens, M. 1991. In die hemel eet 'n mens mieliepap. Johannesburg: Perskor.

McClelland, D.C. 1961. The achieving society. New York: Free Press.
Mo, W. \& Shen, W. 1997. Reexamining the issue of authenticity in picture books. Children's literature in education, 28(2):8593.

Parsons, W.S. \& Totten, S. 1997, 25 Nov. Guidelines for teaching about the Holocaust [Online]. Available: www.ushmm.org/ education/guidelines.html

Pausewang, G. 1996. The final journey. Translated by Patricia Crampton. London: Viking.

Richter, H.P. 1987a. Friedrich. Translated from the German by Edite Kroll. Harmondsworth, Middlesex: Puffin.

Richter, H.P. 1987b. I was there. Translated from the German by Edite Kroll. New York, N.Y.: Puffin.

Rupert, R. 1995. 'n Roofvoël uit die Ooste. Cape Town: Human \& Rousseau.

Shain, M. 1995. The roots of anti-Semiticism in South Africa. Johannesburg: Witwatersrand University Press.

Tötemeyer, A. 1984. The racial element in Afrikaans children's and youth literature. $\mathrm{PhD}$ thesis. Stellenbosch: University of Stellenbosch.

Uhlman, F. 1994. Reunion. London: Flamingo Modern Classics.

Wild, M. \& Vivas, J. 1992. Let the celebrations begin. Norwood, South Australia: Omnibus Books.

Wood, N. 1992. The Holocaust: historical memories and contemporary identities. Media, culture and society, 13(3):357379.

World Council of Churches. Programme to combat racism in children's and school textbooks. Office of education. 1979. First workshop on racism in children's and schooltextbooks, Germany, 13-18th Oct. 1978. Geneva: The Council. 